Volume 3, No. 3, September - December 2018 ISSN: 2503-4235 (p); 2503-4243 (e)

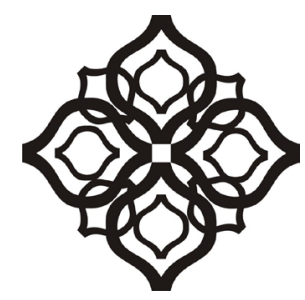

Shirkah

Journal of Economics and Business 


\section{Shirkah}

Journal of Economics and Business

Vol. 3, No. 3, September-December 2018

ISSN: 2503-4235 (p); 2503-4243 (e)

\section{Editor in Chief}

Dwi Condro Triono

\section{Managing Editor}

Jasanta Peranginangin

\section{Editorial Boards}

Abdul Azim Islahi,

Islamic Economics Institute, King Abdulaziz University, Saudi Arabia

Abu Umar Faruq Ahmad,

UBD School of Business and Economics Universiti, Brunei Darussalam

Cedomir Nestorovic,

ESSEC Business School Asia Pacific, Singapore

Fitri Wulandari,

Faculty of Islamic Economics and Business, IAIN Surakarta, Indonesia Johan Fischer,

Department of Social Sciences and Business Roskilde Universitetscenter, Denmark Muhamed Zulkhibri,

Islamic Research and Training Institute, Islamic Development Bank, Saudi Arabia M. Kabir Hassan,

Department of Economics and Finance, University of New Orleans, United States Musa Asy'arie,

Faculty of Islamic Economics and Business, IAIN Surakarta, Indonesia Nunung Nurul Hidayah,

Aston Business School, Aston University, Birmingham, United Kingdom

Saim Kayadibi,

Department of Economics, Kulliyyah of Economics and Management Science, International Islamic University Malaysia, Malaysia 
Shaikh M Ghazanfar,

Departement of Economics, University of Idaho, Russian Federation

Sigit S. Wibowo,

Department of Management, Faculty of Economics and Business, Universitas Indonesia, Indonesia

Vihang R. Errunza,

Desmarais Global Finance Research Centre, Desautels Faculty and Management, McGill University, Canada

\section{Assistant to Editor}

M. Endy Saputro

M. Zainal Anwar

Shirkah Journal of Economics and Business is a peer-reviewed journal published three times a year (January-April, May-August and September-December) by Faculty of Islamic Economics and Business, Institut Agama Islam Negeri (IAIN) Surakarta Central Java, Indonesia. The main objective of Shirkah is to offer an academic space of exchange ideas and initiate the increase number of qualified article produced by postgraduate students, practitioners and academicians.

\section{Editorial Office}

Ruang Jurnal Shirkah

Lantai Dasar, Sayap Barat, Fakultas Ekonomi dan Bisnis Islam, IAIN Surakarta

Jln. Pandawa No. 1, Kartasura, Sukoharjo, Jawa Tengah Kode Pos. 57168

Phone (+62271) 781516 Fax: (+62271)782336

E-mail: shirkahjournal@iainsurakarta.ac.id; shirkahiainsurakarta@gmail.com Website: http://shirkah.or.id/ 


\section{Shirkah}

\section{Journal of Economics and Business}

Vol. 3, No. 3, September-December 2018

ISSN: 2503-4235 (p); 2503-4243 (e)

\section{Table of Contents}

\section{Articles}

Addiarrahman

Ekonomi Kemakmuran Bersama

Indonesian Islamic Economic Thought of KahrudinYunus

Noviy Hasanah

Pasar Resisting Mall

A Cross-Cultural Ethnographic of Economic Traditional Market

Muslich

Implanting Religious Practices

Economic Behavior of Kemloko Tobacco Farmers

Arfah Habib Saragih

Generation XYZ's Perception on Zakat Mal

and Tax A Planned Behavior

Wenda Wahyu Christiyanto, Mardi Astutik

Integrated Marketing and Customers' Decision Saving Funds in Islamic Banks

Sri Walyoto

Carbon Costs of Indonesian Forested Land Conversion to

Oil Palm Plantations 


\title{
Implanting Religious Practices Economic Behavior of Kemloko Tobacco Farmers
}

\author{
Muslich \\ Sampoerna Foundation \\ muslihduoh@gmail.com
}

\begin{abstract}
Tobacco from Kemloko Village has expressively attracted the attention of large companies such as Gudang Garam, Djarum, Sukun, Djambu Bol, Noroyono, and Bentoel. The Kemloko Village Community mostly works as a tobacco farmer, which is as many as $64.8 \%$ of total residents. In addition to these economic activities, the people of Kemloko Village are also active in carrying out traditional religious rituals (congregational prayers, tahlil dhikr and grave pilgrimage, ritual recitation, and slametan) led by village kyai. The kyai concurrently plays a role as important figures in the community, where the santri and society learn to adapt the outside realities, including the economic sphere. This article discusses the complex relationship of tobacco economic activity and the religious practices of the Kemloko Village community, arguing that the two factors makes traders (baskets and bosses) take advantage of the religious behavior of the elder kyai (as a source of authority) while the farmers get more profits.
\end{abstract}

Keywords: tobacco farmers, religious practice, kyai, cultural brokerage

\section{Introduction}

Islam and economics are two things that cannot be separated from each other. The presence of Islam brought by the Prophet Muhammad would be inseparable from economic one. The success of the mission of Muhammad got involve the role of his wife Khadija, a wealthy merchant of his era. Muhammad himself, at first was a trader who worked for Khadija (Jaelani, 2007: 180-182). In addition, in Nusantara archipelago, 
Islam was being spread through trade (Syam, 2005, p. 63; Castles, 1982, p. 31; Bruinessen, 1995, p. 189). In fact, Drewes (1968, p. 443) stated that even though enclaves of the Islamic community on Java had appeared near the end of the 13th century, yet the Islamic progress only began after the arrival of Muslim traders from India around 1400 (Schricke, 1960, p. 25; Horikoshi, 1987, p. 37).

In the development of Islam, the relations between Islam and the economics have continuously occurred until now. Kyai as Islamic religious leaders have been teaching santri in various regions. The kyai network has not only ensued on the basis of scientific construction and teacher-student relations, but trade relations also. The majority of the kyai living in the villages are large landowners. In doing so, the kyai has an "absolute" role in their students. They also became important figures in the community (Kartodirdjo, 1991, p. 65). A kyai has not only been a cultural broker (Geertz, 1960), for which students and society learn to see modernity outside their communities. The kyai has also been a real entrepreneur who in his charity builds networks and penetrates all regions, starting from the small community such as farmers, market traders, farm laborers, even national entrepreneurs (Horikoshi, 1987, p. 229).

Studying religion and economics can not ignore Weber as a beginner scholar who examines this topic. His work the Protestant Ethics and the Spirit of Capitalism would have been a basis to understand the rise of capitalism dealing with the Protestant spirit in Europe at that time. Such religious ethics as ascetic values, restraint of lust, and submission to the Church teachings have been a standard for the progress of one's life. From Weber point of view, this article underlines that the relationship between economy and religion would have been a real thing happened in the society (Weber, 1930, pp. 155-183). Furthermore, Geertz who did longitudinal research in Tabanan Bali and Modjokuto East Java argued 
that a group of small traders and traditional small entrepreneurs who were driven by their religious sense had been a driving force for the growth of the economics in the regions. They were marginalized groups who lose their self-esteem. They want to restore their dignity through systematic and rational pursuit of wealth (Geertz, 1963, pp. 28-81). In line with Weber's and Geertz's, Siegel stated that religion has a salient role in the growth of the economics (1978, pp. 187-227). The trade relations that occur in Bieruen (Aceh) consider more about moral issues based on religious teachings. To conclude, religious behavior was a measure of the growing trade practices of the Bieruen people.

In contrast to these findings, Castles (1982) revealed that the pious Muslims (santri), which he defined as a middle group, turned out to fail maintaining their business while dealing with Chinese domination. Abdullah (1994), however, found that some businessman who get involve in Muhammadiyah school have proved to be able to develop economics activities for themselves. Their successful business made Chinese traders did not exist in the Jatinom, Klaten, Central Java. These pious Muhammadiyah businessmen have been an important actor in the regional economics. They also established Islamic schools and sent their children to Islamic boarding schools. In addition, Huub de Jonge (1989) discussed the relationship between trade and the development of Islam, describing ethnographically Parindu with tobacco activity that underwent symptoms of commercialization along with the development of Islam. Purifying Islamic teachings from local traditions has easily occurred under the influence of the juragan and kyai. Moreover, the traders have allocated a portion of the funds from their tobacco trade for religious activities. This action got a very good response in the community, affirming the position of power of the big traders and their families (Jonge, 1989, p. 284; see also (Botticini \& Eckstein, 2007; Fatchan, Amirudin, \& Soekamto, 2015; 
Nigh \& González Cabañas, 2015; Omoush, 2018; Robin, Kosakowsky, Keller, \& Meierhoff, 2015).

This article proposes to examine the relationship between tobacco economic activity and religious practices of Kemloko Village community. First, this article depicts the religious practices of the Kemloko Village community, especially the behavior regarding diverse teaching and ritual as manifested in daily activities. Second, this article discusses the dynamic relationship that is built between tobacco economic activity and the religious practices of the Kemloko Village community. The article argues that traders (bakul dan juragan) take advantage of the religious behavior of the elder kyai (as a source of authority) and the community to gain profits.

This article has been derived from the ethnographic research that “... has aim to grasp the native's point of view, its relation to life, to realize its vision and its world" (Spradley, 1997, p. xviii). For some considerations, I stay at least one week each time at the research location to then have to go down the mountain for other activities. I have participated in direct observing and even involved in mining activities such as nurseries, land management, harvesting, and crops plantation. I was being often involved in the dynamics of the religious life of the Kemloko villagers through practicing routine rituals (prayers at the mosque, ziyarah kubur [pilgrimage to the tomb], and rukun tetangga meeting).

\section{Religion and Tobacco}

The cigarette has slightly significant contributed to the third rank after income tax and value added tax. However, even though in 2007 the value was IDR 44 trillion, cigarette in Indonesia was still the lowest in the world, only 30 percent. Compare to cigarette production in other countries, such as; Japan (61 percent), China (40 percent), India (72 percent), Thailand (75 percent), Malaysia (49-57 percent), Philippines 
(64-49 percent), and Vietnam (45 percent). Only with Laos cigarettes in Indonesia get more than that of percentage, which is 20 percent. Kemloko village is being located on the slopes of Mount Sumbing, belongs to Tembarak District, Temanggung Regency. The majority people are tobacco farmers. Cleft tobacco, especially growing in southern Sumbing, is very famous. Such national cigarette companies compete to get over it as Gudang Garam, Djarum, Sukun, Djambu Bol, Noroyono, Bentoel. Gudang Garam has been the largest warehouse owner in Temanggung. The cleft tobacco contains high level of nicotine, in doing so it often boasts their tobacco as the best tobacco in the world.

It is important to note that the majority of Kemloko villagers earn their living as tobacco farmers. There is no clear information when they started planting tobacco in this area. Their ancestors have actually planted local tobacco. At that time, the production of tobacco was only for self consumption, selling in local markets in the Temanggung area. In the 1970s, such big cigarette factories as Gudang Garam, Djarum and Bentoel were established in Temanggung. Of course this condition changes the ways of the farmers producing tobacco. The big market has enforced changing their cropping patterns. They become more seriously to plant tobacco as their main commodity and their source of income.

Changing orientation of tobacco trade has driven raising the new pattern of land ownership. Along with the opening of national tobacco companies in Temanggung, the market then has been dominated by the trade. Converting land ownership had slowly been occurring. As a result, the land owning in the hands of juragan and bakuls was inevitable. Some farm workers were increasingly widespread. Since the 1998 monetary crisis, more Kemloko people have travelled abroad to become migrant workers. The majority of them work as domestic servants in Malaysia. At least 70 people have left to this neighboring country. There is no official 
data on this, because they usually do not report their departure to the village government.

The greed of the juragan and bakul has eliminated the land of small farmers. Mustain (2002, p. 354) has explained its impact to some folds. First, some farmers got social degradation and loss of their existence. Second, farmers experiencing horizontal mobility, from farmers to industrial workers; while vertical mobility has been decreasing, from small landowners farmers to farm laborers. Outside the tobacco season planting, such farm laborers go to the city to become laborers in the market, construction workers or other menial jobs. Others went to Kalimantan to work in the area of oil palm plantations as laborers.

Third, the dramatically changing condition has ensued Kemloko Village as being classified as poor village, a family is being considered to have not reached the minimum size of prosperity. Poverty has been a daily portrait of the Kemloko; there are more who have poor homes than those with luxurious homes. An ordinary house is occupied by two families, due to narrow land while their economics is not well established. Those who are able to send their children to school are only community leaders who are economically well-established.

The majority of Kemloko residents are farmers, 1,670 people (64.8\%). Mostly have been working as farm laborers, 640 people $(24.8 \%)$; while those who work as entrepreneurs are 60 people $(2.3 \%)$, five civil servants $(0.2 \%)$, a mechanic $(0.04 \%)$, traders 128 people $(4.9 \%)$, carpenters 29 people (1.1\%), and 44 masons (1.7\%) (PMD Temanggung, 2007). Along with $64.8 \%$ of farmers and $24.8 \%$ of farm laborers, in the tobacco season all people with various profession get involve in the tobacco business. Albeit only about six months running, tobacco season spends a lot of activities that invite economic income to Kemloko people. They get involve since the process pembibitan (nursery) to selling dried tobacco to the tobacco company warehouse. 
The farmers of Kemloko Village put it simply has been divided into two large groups. The former consists of such farmers as farm laborers, farmers and craftsmen; while the latter is a trader consisting of juragan and bakul. Above them are warehouse of cigarette factories. In addition, majority Sumbing people are Muslims with the NU (Nahdlatul Ulama). Religious rituals that are carried out daily include shalat jamaah, tablil dhikr, grave pilgrimage, and slametan. They have respect and practiced ancestor tradition, carry out slametan; their religious practice based on universal Islamic values with local constructs. The Kemloko people have a very strong relationship with kyai. The kyai for them is not only a place to consult about various problems, it also becomes a guide to life, norms, and values in community life (see Horikoshi, 1987, p. 228; Ojong, 2018).

For majority of Kemloko people, Mbah Mat has been considered an old respected kyai. The kyai sepuh would a call addressed to the kyai who has the depth of his religious knowledge (tafaqquh fi-addin), the breadth of his experience, and charismatic wisdom. The kyai has been also considered to have extraordinary abilities. Besides being able to provide various advices on various problems of the people, the kyai has been considered to have ability to predict things that will happen in the future. Accuracy of predictions is what makes people really respect him. The Javanese call it the ability weruh sakdurunge winarah (knowing before happen).

The kyai sepuh has been considered to have a close relationship with Allah. People call it waliyullah (man who Allah loves to him). They spend almost all of its time to pray for Allah. He prayed for many people. He does not willing to sleep for the evening prayer when most people are asleep. He also does not have much time to take rest because many guests came to his house. They visited Mbah Mat in hopes of getting prayers and blessings, especially for that of their needs and hopes. In short, the kyai were being exhausted for the affairs of the people and not for personal matters. 
Kemloko Village people believe that Mbah Mat Watucongol has long been one of the kyai sepuh. He is a sacred person. He can see things invisible. The words that came out of Mbah Mat were believed to be auspicious, because they were deriving from batin. All acts of his behaviour are a sign for most people. When he dislikes something, it means usually hinted at by signs. For example, before 1998 Indonesian reformation, Mbah Mat had been visiting traders in the markets and kiosks. It was being interpreted by the Kemloko people that Mbah Mat has encouraged people to diligently trade to obtain a halal fortune. During reformation era, Mbah Mat habits have changed. He was no longer going to markets and kiosks. His daily habit was being travel from mountain to mountain. In this regard, the Kemloko people interpreted it as a form of Mbah Mat's concern for unstable natural phenomena.

These strange things about Mbah Mat have widespread in the communities of Mount Merapi, Merbabu, Tidar, Sumbing and Sindoro. Mbah Mat's fame was also being seen from the number of guests who came to him to ask for his blessings. Mbah Mat is able to compromise all levels of the people, such as farmers, market traders, farm workers, national officials and entrepreneurs (Horikoshi, 1987: 229). There have been many officials of this country who came to Mbah Mat to ask for blessings. Most of the candidate of lurahs in the Merapi, Merbabu, Tidar, Sumbing, Sindoro mountain areas had once attended Mbah Mat before they advanced to the village election. The French Prime Minister, Jacques Chirac, once came to Watu Congol just to meet Mbah Mat.

The Mbah Mat special feature is about his ability to see halal money or not. Every time guests arrive, they will leave money in an envelope as a gift. The money was being collected. A santri was asked to sort out money; while Mbah Mat said, "Wah, durung pinter kowe" (wow, you're not smart). He sorted out the money for his own in order to set the halal money 
and illicit illicit. The halal money has been obtained in right ways, while illicit money has been obtained in prohibited ways (whether coming from fraudulent, lying, manipulating, or corruption). Another story was about a thief who will take things from Mbah Mat house. Before the thief arrived, Mbah Mat asked his wife to prepare rice dishes complete with vegetables and side dishes. On the night, the thief entered the house. After taking a lot of things, he has tried to find a way out. However, he was confused and exhausted because he didn't find a way out. The thief just sat tired in exhaustion. Mbah Mat met the thief and told him to eat enough.

Entering season of tobacco, the Kemloko farmers went to Mbah Mat to consult about tobacco business. Mbah Mat gave a signal to cultivate tobacco in small amounts, lots, mediocre or not at all. It was a signifier of the harvest situation, not yet known whether it would be good or not. As stated earlier that the success or failure of the tobacco harvest depends on two things, namely the season and the factory. Once in 1994 and 1999 the tobacco harvest failed miserably because it rained at the time of harvest. All tobacco was being damaged and the selling price drops more than half of the normal price. Kemloko people believed that Mbah Mat could read the situation appropriately was what driven the people loyal to Mbah Mat. At least four times a year Kemloko people would be visiting Mbah Mat.

In addition, they also made a pilgrimage to Mbah Dalhar at the Mount Pring cemetery, near the house of Mbah Mat. Mbah Dalhar is Mbah Mat father. Like Mbah Mat, Mbah Dalhar has been known as a trustee. His tomb was crowded with people from various regions of Java. Usually, Kemloko people visit Mbah Mat and make a pilgrimage on the month of Sura, during the fall of tobacco, before harvest, after harvest, and at the time of Mbah Dalhar's haul. Sowan (visit) and pilgrimage have been conducted together by renting a bus. It often happens, the committee only provides two buses, yet it needs teen buses. For this visit, people are willing to spend their own money. 
Visiting the kyai and going to pilgrimage became a signifier of piety. Kyai and "holy places" is a reminder to conduct good morals in society (Woodward, 1988, p. 58). "The saint is an exemplar" (Brown, 1987) or an ideal figure beyond the most people (Bowen, 2002, p. 246). In the figure of Mbah Mat, the kyai does not merely become a cultural broker (Geertz, 1960) but also becomes a mirror to look at themselves to see all the mistakes that have been done. Kyai also become hope and help when there is a trouble (Horikoshi, 1987, p. 225). Kyai would be a means for laity people to better practice religious teachings. The kyai became charismatic figures for the people (Horikoshi, 1987, pp. 211-236). The strong influence of the kyai among the residents of the Kemloko Village made the relationship of patron-client, and therefore the loyalty of the people towards him was also undoubted (Kartodirdjo, 1991, p. 65).

\section{Making Economics and Practicing Religion}

The author would analyze the relationship between tobacco economic activities and the religious practices happened in the Kemloko Village under Pierre Bourdieu's theory. Social space and social fields; according to Bourdieu, people such as Kemloko Village is social spaces. Social space refers to the whole conception of the social world. It has been formed because of a collection of existing domains and also because of "contact points" (Harker et al. 1990: 12). The domain is the relation between the objective position occupied by the agent (individual or institution) on the basis of the capital, which enables him to gain access to a variety of benefits (capital) in the domain and relations with other objective positions (Bourdieu and Wacquant, 1992: 97).

Bourdieu's domain is a dynamic structure. The domain is not just a matter of "defining" and "defined" or "forming" and "formed" as said Anthony Giddens. It has been formed on the basis of "meeting points" 
between social agents (language, lifestyle, knowledge, interests, and so on). The agents who make the kyai as a place to rely on various daily problems have knowledge and attitudes about how to behave when facing the kyai, and tend to "meet" with other agents with the same characteristics, even though they may differ in position. For example, juragan and farm laborers who meet in the same cultural realm would be ta'dhim (respecting) the same kyai.

At the same time, agents can become "members" more than one domain. An agent (actor) can be a farm laborer as well as a religious figure. It could also turn out that a bakul is also a member of a tarekat, which means he is in the economic domain as well as the cultural domain. In each domain they occupy, agents always try to strengthen their position. This is what makes the realm fluid and dynamic so that it is difficult to set boundaries (Bourdieu and Wacquant, 1992: 100). To Bourdieu, the domain system has contained social space, like a planetary system, because social space really is an integral domain. Each domain has its own strength. Each domain is situated in a large domain which also has strength, its own structure, and so on (Harker et al., 1990, pp. 45-46).

Agent, variety of capital and objective position; agents can be individuals and institutions. Through the variety of capital they have, agents will contest and compete with each other to determine their respective objective positions. There are four types of capital that can determine the agent's objective position, namely economic capital, social capital, cultural capital, and symbolic capital (Richardson, 1986; Bourdieu and Wacquant, 1992, p. 119; Haryatmoko, 2003, pp. 11-12; Allan, 2006, pp. 176-178). Economic capital is the level of agent ownership of wealth and income. Social capital is a network of relationships that makes it easy for agents to accumulate other forms of capital. Cultural capital is the ownership of agents for material objects that are considered to have 
high prestige (objectified cultural capital), knowledge and skills that are recognized by official authorities (institutionalized cultural capital), and habits (clothing styles, speech, tastes, body movements distinctive, and its parts) which is a manifestation of the agent's objective position (embodied cultural capital). Symbolic capital is a variety of signs (cultural capital) that can give legitimacy to the agent's position, perspective and social actions so that they are considered the most legitimate by other agents. He has the ability to "shape the world" (the power of world-making). The four capitals are useful to support the determination of reproduction of agents' social positions (Haryatmoko, 2003, p. 12).

In practice, to strengthen objective positions in the realm, capital can be exchanged (reconversion) with one another (Bourdieu, 1994, pp. 125-175). Economic capital is the easiest type of capital to be exchanged with other capital. Whereas the most valuable is the conversion of various types of capital into symbolic capital because it allows the agents who have them to define other agents, represent them, and form a "social world" that is recognized as validity (symbolic power), as Bourdieu (1995, p. 166) asserts, "Symbolic power is a power of constructing reality ... ". In this way, the agent then gains economic, cultural, and other benefits (which can strengthen his position in the realm), which are invisible because they are enveloped in symbolic capital (Bourdieu, 1977, p. 183; Wacquant, 1994, p. 9).

The objective position of the agent has been determined by its ownership of capital and its relation to the objective position of other agents. There are three measures of ownership of capital (Haryatmoko, 2003, pp. 12-13; Allan, 2006, pp. 182-183), namely: first, ownership of agents for the four types of capital (economic, social, cultural, symbolic); second, volume (number) of each capital owned by the agent; and third, the relative weight of various types of capital in the realm, which is highly 
dependent on the characteristics of the domain, for example symbolic capital has the highest relative weight in the political sphere, economic capital in the economic domain, cultural capital in the realm academic or religious. If the agent has four types of capital, the volume is large and its relative weight is high, and it is in relation to another agent whose characteristics are opposite (the type of capital owned is incomplete, the volume is small, and its relative weight is low), so it occupies the dominant objective position in realm.

Habitus. In addition, the domain which is the objective dimension of structure, the agent also adheres to the subjective dimension Bourdieu conceptualizes as habitus. It consists of various dispositions that form a classification system (Bourdieu, 1977, p. 214) which is a conceptual representation (knowledge, feelings, attitudes) of the reality experienced by the agent in accordance with its objective position in the realm. However, habitus is not an abstract set of values or theoretical conceptions, codified, with clear reference sources, and consciously studied by agents. It is something that is produced and reproduced because it is socially accepted.

Habitus forms vary. It can be in the form of principles, values, for example the Javanese must be respectful, maintain good manners, respect towards the kyai. He can also manifest in typical body movements, such as how to talk, walk, gesture when passing other people, and so on. Whatever its form, habitus is internalized to the agent and unwittingly guides its daily social actions. Habitus is not only attached to individuals, but also classes. The same individual habitus will group (homology) to form class habitus. Habitus has been formed from a combination of social position and agent's personal history (social origin, work and education). Certain social positions in the realm, for example rich people such as juragan and bakul in Kemloko, tend to produce juragan and bakul habitus, such as tastes, ways to eat, dress styles, body movements, etc., which are different 
than poor people like farm workers. Habitus develops along with the expansion of agent relations with other agents with different habitus. It is a generative structure (Harker et al., 1990, p. 43).

Habitus forms a kind of classification system. Along with that system agents organize their social actions, perceive and appreciate other agents' social actions. It is inherent as well as manifesting in agents (ways of talking, walking, eating) so that it automatically (unconsciously) guides its social praxis (Bourdieu, 1984, p. 466). This is what the Giddens call the term practical awareness (Giddens, 1984). In its original objective position, habitus tends to reproduce itself, for example child habitus tends to be the same as parents. Once formed, habitus tends to be a kind of reference for subsequent agent behavior (Bourdieu, 1979, p. viii). This makes habitus durable. However, at some point, habitus also adjusts to changes in the realm. Therefore, habitus also has a changing nature (transposable). With this perspective, it can be concluded that habitus does not determine the agent's social praxis, but mediates between agents and the social world that surrounds them.

Symbolic fighting and symbolic power; in Bourdieu's view, the essence of each realm is the battlefield between agents to strengthen its position (in the realm). For the dominant he is the field to maintain his position, while for the marginal to take it (Bourdieu and Wacquant, 1992), "As a space of potential and active forces, the field is also to change the configuration of these forces. Furthermore, the field of relations between positions of force undergirds is the most favorable to their own products." Contestation occurs at the symbolic level (discourse) or, according to Bourdieu (1994, pp. 244-256; 1995, pp. 239-248) as being symbolic struggle (symbolic struggle). However, the symbol or discourse being contested is not something that appears solely as an agent's creativity, as assumed by the agent's approach. He is the dialectical result between domains with habitus 
(agent's subjective structure). In doing so, it is a symbol that has both a domain and a habitus.

Underlying the battle between agents in the realm is the difference in objective positions between them. Because capital is limited in number (but it is important to have it in order to guarantee a position in the realm) then with its capital, agents try to accumulate capital. This is the logic of capital underlying the battle in the realm. What the agents want to achieve or maintain in the fight is the dominant position in the realm, which is characterized by ownership of various capital types that are complete, large volumes, and high relative weights. If this is achieved, agents will have the power to define other agents and claim themselves as representations of them and form their own version of the "social world" which is considered legitimate of symbolic power (Bourdieu, 1995, p. 170; Bourdieu, 1977, pp. 159-183). He can hide his real interests (misrecognition), namely the accumulation of capital in order to strengthen his dominant position in the realm. Because of this legitimate recognition, the accumulation of capital by agents to maintain its position in the realm is easier.

Bourdieu analogizes the battlefield as a game. There are codes and rules that must be mastered in order to be involved in the game. Those who master it well (feel for the game, practical sense, sense of the game (Bourdieu and Wacquant, 1992, pp. 120-121) will control the game (dominant position), while those who don't, simply become amateur players or spectators (marginal position). In an effort to master the codes and rules in order to be the controller of the game, there was a battle between agents. The dominant ones try to maintain their position, while the marginal ones try to take it. The mechanism used to maintain or usurp the dominant position is social reproduction (Bourdieu and Passeron, 2000, pp. 3-31). This is an attempt to maintain the social order. For those who occupy a dominant position, this is important to maintain because 
that's where the dominance is guaranteed. Whereas for the marginalized, by learning the codes and rules of the dominant realm of the game, starting from knowledge, skills, lifestyle, ways of speaking, body movements, etc., the objective position can increase, maybe even reach a dominant position.

Social reproduction occurs through certain mechanisms that connect between domains, capital, and habitus. The objective domain which includes objective positions on the basis of capital ownership is converted into a symbolic domain by using symbolic capital. When it becomes a symbolic realm, the objective realm gains legitimacy and is considered reality. This is possible because symbolic capital has the ability to construct and form recognition that results in and legitimizes the relations between positions in the objective domain. In subsequent developments, symbolic capital crystallized into cultural capital in the form of knowledge, skills, values, rules that must be learned because they are considered as something legitimate. Cultural capital that is attached (embodied or internalized) to the agent then becomes habitus. Habitus screens the choice of agent actions to suit their realm. At this point the process of social reproduction takes place.

Social reproduction is carried out with certain strategies. First is the strategy of biological investment, inheritance, and education, which is carried out in the family domain; second, is the economic and symbolic investment strategy, which occurs in the social sphere (Haryatmoko, 2003, pp. 15-16 (Ojong, 2018)). Biological investment strategies are intended to ensure inheritance of capital and an increase in objective position by controlling the number of offspring. The forms vary, ranging from guarantees to family health, choices of food consumption, rest patterns, types of entertainment and sports. Inheritance is an effort to guarantee wealth in the form of economic capital which has an important role in the relations of power and struggle in the realm. The education investment 
strategy is intended to prepare agents who have sufficient ability to receive inheritance or improve objective positions in the realm. An economic investment strategy is an attempt to increase the number and form of capital in order to achieve or strengthen a dominant position through various means, such as cooperation, marriage, exchange of money, and others. The symbolic investment strategy is intended to maintain perceptions that can increase or maintain the validity of the positions occupied by the agent.

In Bourdieu's view, research also reveals how dominant parties produce and reproduce their power through the capital they have. They tend to produce orthodoxa, a single discourse that must be followed by other competing agents. And this will be very different from those who are marginal or vice versa who tend to produce hetherodoxa, a counter discourse on the dominant discourse. The relationship between agents, habitus, and the domain in Bourdieu's theory is summarized in the figure below.

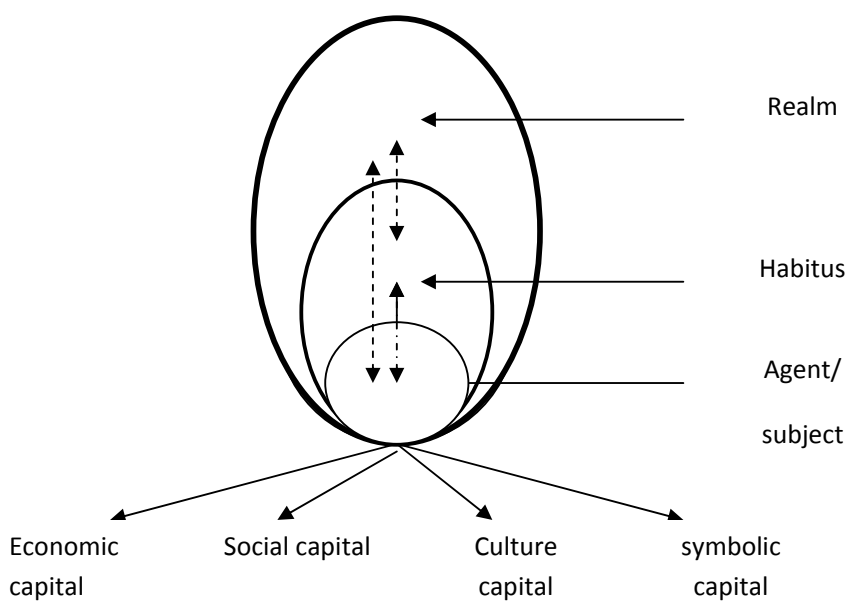

Figure 1. The position of agents, habitus and domains 
The domain depicted in this article is the economic sphere and the realm of religion which has its own strengths. They are in the same social space. The economic sphere is more or less describing the tobacco economic activities starting from the process of preparation, processing to trading. Meanwhile the religious realm describes religious activities along with teachings (values, norms, doctrines) that guide religious rituals and practices in daily activities. Under Bourdieu's theory of agents, this article reveals two large groups in two research variables. Agents of tobacco economic activities consist of farmers and traders. Farmers themselves consist of: (1) farm laborers, (2) farmers, and (3) tobacco craftsmen, while traders consist of: (1) bakul, and (2) juragan. Agents in religious practice variables consist of kyai and community members as devotees. The first consists of: (1) cottage clerics, (2) mosque scholars, and (3) village clerics. Meanwhile the community members consist of: (1) tarekat followers, and (2) citizens who do not follow the tarekat (see also Schneider, 2014).

Each agent has its own capital. They compete with each other for capital. Achieving an objective position as a dominant party is the expectation of each agent, whether consciously or not. What is clear, as Bourdieu states, is that the dominant party tends to maintain power through a variety of capital already held, while the marginal parties try to seize it. The positions of agents (actors) both in the tobacco economic variable and in religious practice variables are not static.

They exchange places, and therefore not something stagnant. For example, farm workers whose economic capital is low in the economic sphere do not necessarily occupy a low position in the realm of religion. From this reason, it can be understood that Kemloko Village as a community (social space) consists of various structures (domains) which include: history (myths, trends and changes), economics, education, socioreligious, and politics. The domains above intersect to form Kemloko as 
a separate entity. The economic sphere (tobacco economic activity) and the realm of religion (religious practices) are the two dominant domains in Kemloko, without ignoring mutual relations between other domains.

\section{Conclusion}

The dynamics of the relationship between tobacco economic activity and the religious practices of the Kemloko community are being illustrated in several aspects. First, the greed of the market has caused traders, whether consciously or not, to behave in lulang macan hoods (using the great name and prestige of old kyai and religious practices for purely business purposes). The dominant party produces and reproduces power by getting involved in religious administration by dominating the construction of mosques, building relationships with supra village kyai, and making pilgrimages to different locations.

Second, these behavioral behaviors break down in a variety of responses by allowing the practice of teaching to continue and issuing supoto (expletive). The farmers did not involve the traders in religious activities (such as mujahadah, and deeds). This practice of worship is carried out by those who are members of the tarekat. While the majority of bosses and baskets are not members of the tarekat. Islamic knowledge of the local community increased because traders allocated part of the funds from their tobacco trade for religious activities. This has received a very good response in the community, besides implicitly means affirming the position of power of the big traders and their families. Traders (baskets and skipper) through the pattern of cheats tend to be greedy and behave in lulang macan hats. By not reducing their level of trust in the old kyai as a source of authority, the Kemloko Village community has its own mechanism to maintain their diversity. 


\section{References}

Abdullah, Irwan. (1994). The Muslim Businessmen of Jatinom, Religious Reform and Economic Modernization in a Central Javanese Town. Netherland: Universiteit van Amsterdam.

Abdullah, Taufik (ed) (1978). Agama, Etos Kerja dan Perkembangan Ekonomi. Jakarta: LP3ES \& Buku Obor.

Botticini, M., \& Eckstein, Z. (2007). From farmers to merchants, conversions and diaspora: Human capital and Jewish history. Journal of the European Economic Association, 5(5), 885-926. https://doi. org/10.1162/JEEA.2007.5.5.885

Bourdieu, Pierre and Loïc J.D. Wacquant. (1992). An Invitation to Reflexive Sociology. Chicago: The University of Chicago Press.

Bourdieu, Pierre. (1977). Outline of a Theory of Practice. Translated by Richard Nice. Cambridge \& Massachusetts: Harvard University Press.

Bourdieu, Pierre. (1994). Distinction: A Social Critique of the Judgement of Taste (Seventh Printing), translated by Richard Nice. Cambridge \& Massachusetts: Harvard University Press.

Bourdieu, Pierre. (1995). Language and Symbolic Power (Fourth Printing). Cambridge \& Massachusetts: Harvard University Press.

Bowen, John R. (2002). Religions in Practice, An Approach to the Anthropology of Religion. Massachussets: Allyn \& Bacon A Pearson Education Company.

De Jonge, Huub. (1989). Madura dalam Empat Zaman: Pedagang, Perkembangan Ekonomi, dan Islam, Jakarta: Gramedia.

Fatchan, A., Amirudin, A., \& Soekamto, H. (2015). Education model "bandongan" for farmers society of agricultural skills training in the background of sosioculture "pesantren" in East Java. Mediterranean Journal of Social Sciences, 6(5), 515-523. https://doi.org/10.5901/ mjss.2015.v6n5p515 
Geertz, Clifford. (1960). The Religion of Java. Chicago: The University of Chicago Press.

Giddens, Anthony. (2003). The Constitution of Society, Teori Strukturasi untuk Perubahan Sosial (transl). Pasuruan: Penerbit Pedati.

Gilbert, Alan \& Josef Gugler. (1996). Urbanisasi dan Kemiskinan di Dunia Ketiga (transl). Yogyakarta: Tiara Wacana.

Harker, Richard, Cheelen Mahar, and Chris Wilkes. (1990). (Habitus x Modal) + Ranah $=$ Praktik (transl). Yogyakarta: Jalasutra.

Haryatmoko, (2003). Landasan Teoretis Gerakan Sosial Menurut Pierre Bourdieu, Menyingkap Kepalsuan Budaya Penguasa, Majalah Basis No. 11-12, tahun ke-52, Nov-Des 2003, Yogyakarta.

Horikoshi, Hiroko. (1987). Kyai dan Perubahan Sosial (transl). Jakarta: P3M.

Jaelani, Bisri M. (2007). Ensiklopedi Islam. Yogyakarta: Panji Pustaka.

Kartodirdjo, Sartono.(1991).ModernIndonesia, Tradition \& Transformation; A Socio-Historical Perspective (edisi ketiga). Yogyakarta: Gadjah Mada University Press.

Mustain. (2007). Petani Vs Negara, Gerakan Sosial Petani Melawan Hegemoni Negara. Yogyakarta: Ar-Ruzz Media.

Nigh, R., \& González Cabañas, A. A. (2015). Reflexive Consumer Markets as Opportunities for New Peasant Farmers in Mexico and France: Constructing Food Sovereignty Through Alternative Food Networks. Agroecology and Sustainable Food Systems, 39(3), 317-341. https://doi. org/10.1080/21683565.2014.973545

Ojong, N. (2018). Trust, cultural norms and financial institutions in rural communities: the case of Cameroon. Review of Social Economy, 76(1), 19-42. https://doi.org/10.1080/00346764.2017.1300316.

Omoush, M. (2018). Feudal Economy and Rural Settlement of Oultrejourdain and Their Impact on Muslim Farmers under the Rule of the Crusaders (1099-1189). Article in Press. https://doi.org/10.1080/09596410.20 18.1530886 
Robin, C., Kosakowsky, L., Keller, A., \& Meierhoff, J. (2015). Leaders, farmers, and crafters: The relationship between leading households and households across the chan community. Ancient Mesoamerica, 25(2), 371-387. https://doi.org/10.1017/S0956536114000315

Schneider, M. (2014). Between agroecology and tobacco production: An ethnography of the work on land, cosmologies and belonging among Pomeranians peasants. Etnografica, 18(3), 651-669. https://doi. org/10.4000/etnografica.3855

Spradley, James P. (1997). The Ethnographic Interview (Indonesian edition). Yogyakarta: Tiara Wacana.

Tedlock, Barbara. (2000). Handbook of Qualitative Research. California, London, New Delhi: Sage Publication.

Woodward, Mark R. (1988). The "Slametan": Textual Knowledge and Ritual Performance in Central Javanese Islam, Jurnal History of Religions Vol. 28 No. 1 (Agustus). 


\section{Shirkah Author Guidelines}

Shirkah currently offers two routes to submit manuscripts. We highly recommend to submit the articles which are made using OJS (Open Journal System). Feel free register as author soon through visiting http:// shirkah.or.id/index.php/home/user/register. The authors may directly send their manuscripts, along with their resume, to shirkahiainsurakarta@ gmail.com. Please prepare your manuscripts, using following guidelines:

1. Manuscript must be written in English. Submitted articles should not have been published or be under review for publication with another journal.

2. Manuscript's length is about $15-20$ pages, typed in one-half spaced on A4-paper size.

3. Manuscript must include an $150-200$ word abstract and keywords.

4. Manuscript must be arranged as follows: Title, Name of Author, E-mail address, Abstract, Keywords, Introduction (including method if any), Discussion, Conclusion, References.

5. Manuscript's titles not more than ten words.

6. Manuscript must be submitted in Microsoft Word or RTF.

7. Arabic words should be transliterated according to the style of International Journal of Middle Eastern Studies.

8. Manuscript references are preferably derived from the up-to-date references.

9. The author's resume should be submitted separately, consisting of at least full name, institutional address, phone number, areas of studies, and recent publications (if any).

10. Shirkab use APA Style 6th edition (2010) as reference format writing. We suggest the use of a reference manager software such as Mendeley, Zotero, and Endnote at templating the citation style. APA Style to be used is as follows: 


\section{Book with single author}

Swann, G. M. Peter. (2014). The Economics of Innovation an Introduction. Cheltenhum \& Northampton: Edward Elgar.

in-text citation: (Swann, 2014)

\section{Articles in reference books}

Alatas, S. F. (2006). Islam and the Science of Economics in Abu Rabi', I.M. The Blackwell Companion to Contemporary Islamic Thought. USA: Willey-Blackwell (pp. 587-606).

in text citation: (Alatas, 2006)

\section{E-Book}

Hackett, Rosalind (2007). "Religous Dimentions of War and Peace: Introduction." Dalam Gerrie ter Haar dan Yoshio Tsuruoka (Ed.), Religion and Society: An Agenda for the 21st Century (h. 3-6). Retrieved from http:// brill.nl.

in text citation: (Hackett, 2006)

\section{Master's thesis, from a commercial database}

McNieI, D. S. (2006). Meaning through narrative: A personal narrative discussing growing up with an alcoholic mother (Master's thesis). Available from ProQuest Dissertations and Theses database. (UMI No. 1434728)

in text citation: (Mc Niel, 2006)

\section{Doctoral dissertation, from an institutional database}

Adams, R. J. (1973). Building a foundation for evaluation of instruction in higher education and continuing education (Doctoral dissertation). Retrieved from http://www.ohiolink.edu/etd/

in text citation: (Adams, 1973) 


\section{Doctoral dissertation, from the web}

Bruckman, A. (1997). MOOSE Crossing: Construction, community, and learning in a networked virtual world for kids (Doctoral dissertation, Massachusetts Institute of Technology). Retrieved from http:/www-static. cc.gatech.edu/--asb/thesis/

in text citation: (Bruckman, 1997)

\section{Journal article with No DOI}

Bourkhis, K., and Nabi, M. S. (2013). Islamic and conventional banks' soundness during the 2007-2008 financial crisis. Journal Metrics, 22(2), 68-77.

in-text citation: (Bourkhis \& Nabi, 2013).

\section{Journal article with DOI}

Ichwan, M. (2012). The Local Politics Of Orthodoxy: The Majelis Ulama Indonesia in the Post-New Order Banten. Journal Of Indonesian Islam, 6(1), 166-194. doi:http://dx.doi.org/10.15642/JIIS.2012.6.1.166-194

In text citation : (Ichwan, 2012)

\section{Abstract as citation}

Hasan, N. (2012). Islamist Party, Electoral Politics And Da'wah Mobilization Among Youth : The Prosperous Justice Party (PKS) in Indonesia. Journal of Indonesian Islam, 6(1), 17-47. Abstract from http:// jiis.uinsby.ac.id/index.php/jiis/article/view/97

in text citation : (Hasan, 2012)

\section{Mass media article}

Sahal, Akhmad (2014, March 2). Kiai Sahal dan Realisme Fikih.Tempo Magazine, p. 120.

in text citation : (Sahal, 2014) 


\section{Research report}

Fisher, B. S., Cullen, F. T., \& Turner, M. G. (2000). The Sexual Victimization of College Women. Research Report.

in text citation : (Fisher, Cullen, Turner, 2000)

\section{Monograph}

Routray, Bibhu Prasad (2013), National Security Decision-Making in India (RSIS Monograph No. 27). Singapura: Rajaratnam School of International Studies.

in text citation : (Routray, 2013)

\section{Proceeding article}

Sudibyakto, Hizbaron, D.R., \& Jati, R (Ed.) (2009), Proceeding International Seminar Disaster Theory, Research and Policy. International seminar held by Sekolah Pascasarjana, Universitas Gajahmada, Yogyakarta, 8-9 Desember 2009.

in text citation : (sudibyakto and Jati, 2009)

\section{Paper conference/seminar/symposium}

Janutama, Herman Sinung (2011). "Kraton dan Hubungan Antar Agama." Paper presented in Seminar Kraton dan Panatagama held by Center for the Study of Islam and Social Transformation (CISForm), Yogyakarta, 17 November.

$$
\text { in text citation :(Janutama, 2011) }
$$

\section{Online article in web}

Shiva, (2006, February). Bioethics: A Third World Issue. Native-web. Diperoleh dari http://www.nativeweb.org/ pages/legal/shiva.html 


\section{in text citation : (Shiva, 2006)}

\section{Online research report}

Kessy, S. S. A., \& Urio, F M. (2006). The contribution of microfinance institutions to poverty reduction in Tanzania (Research Report No. 06.3). Retrieved from Research on Poverty Alleviation website: http://www. repoa.or.tz /documents_storage/Publications/Reports/06.3_Kessy_and_ Urio.pcif

in text citation : (kessy and urion, 2006)

\section{Holy book}

Qur an, $2(25)$

In text citation : (Q. al-Baqarah 2:25).

\section{Encyclopaedia}

Graycar, Adam (1992). Social Welfare Policy. Dalam Mary Hawkesworth dan Maurice Kogan (Ed.), Encyclopedia of Government and Politics (Vol. 1). London: Routledge.

in text citation : (Graycar, 1992)

\section{Interview}

Sultan Hamengkubuwono X (interview, 2011, April 19)

in text citation : (Hamengkubuwono, 2011)

\section{Documentary film}

Steijlen, Fridus (2008). A Day in the Life of Indonesia [documentary film, 58 minutes]. Leiden: KITLV Press.

in text citation : (Steijlen, 2008) 
Vol. 3 No. 3, September - December 2018 